\title{
Badanie współczynnika tarcia hamulca tarczowego
}

\begin{abstract}
$W$ niniejszy artykule zaprezentowano metodykę badań oraz wyniki uzyskane na bezwładnościowym stanowisku po przeprowadzeniu badań ciernych na kolejowym hamulcu tarczowym. Na podstawie serii badań o charakterze trybologicznym przebadano pary cierne hamulca tarczowego $i$ wyznaczono charakterystyki procesu hamowania $w$ zależności od prędkości hamowania, docisku okladzin do tarczy hamulcowej oraz mas hamujacych. Na podstawie wyników z ciernych badań stanowiskowych wyznaczono zależności wspótczynnika tarcia (chwilowego $i$ średniego), w funkcji zużycia okładzin i prędkości poczatku hamowania.
\end{abstract}

\section{Wstęp}

Ze względu na coraz większe prędkości jazdy pociągów pasażerskich i towarowych, hamulec tarczowy staje się podstawowym urządzeniem hamulcowym zarówno w wagonach, jak i w lokomotywach. Również szereg zalet tego rodzaju hamulca, jak np. stały przebieg współczynnika tarcia w funkcji prędkości w stosunku do tradycyjnego hamulca klockowego, uzasadnia jego stosowanie i to zarówno $\mathrm{w}$ pojazdach kolejowych, jak i w pojazdach szynowych komunikacji miejskiej. Mimo wielu zalet układu hamulcowego, zamocowanie tarcz hamulcowych na osi pomiędzy kołami zestawu kołowego znacznie utrudnia kontrolę zużycia pary ciernej tarcza-okładzina. Wymusza ono na obsłudze i pracownikach zakładów naprawczych wchodzenie pod wagon w celu zdiagnozowania ukła$\mathrm{du}$ hamulcowego, sprawdzenia poprawności jego działania, kontroli zużycia oraz przeprowadzenia niektórych napraw bieżących. W artykule przedstawiono zależności przebiegu współczynnika tarcia w funkcji wybranych grubości okładzin ciernych oraz innych parametrów hamowania uzyskanych po przeprowadzeniu stanowiskowych badań kolejowego hamulca tarczowego w Instytucie Pojazdów Szynowych TABOR w Poznaniu.

\section{Wyznaczenie minimalnej ilości hamowań do oceny statystycznej}

Przed zasadniczymi badaniami stanowiskowymi, wykonano serię 25 hamowań do oceny statystycznej. Badanie miało na celu wyznaczenie minimalnej ilości powtórzeń, zapewniających otrzymanie wyników w zadowalającym przedziale ufności, wynoszącym 95\%, przy przyjętym poziomie istotności, $\alpha=0,05$, przy którym obserwuje się najmniejszy współczynnik zmienności. Analizie statystycznej poddano wartość średniego współczynnika tarcia ślizgowego $\mu$, zmierzonych w 25 próbach przy niezmiennej prędkości początku hamowania wynoszącej $120 \mathrm{~km} / \mathrm{h}$. Pomiar został przeprowadzony po dotarciu okładzin zgodnie wymaganiami zawartymi w Karcie UIC 5413. Każde kolejne hamowanie było poprzedzone chłodzeniem tarczy na wolnym powietrzu poprzez jej swobodny obrót, przez co symulowano jazdę wagonu z prędkością $100 \mathrm{~km} / \mathrm{h}$. Po obniżeniu temperatury tarczy do wartości $60^{\circ} \mathrm{C}$ przerywano jej chłodzenie i rozpoczynano kolejne hamowanie. Wyniki pomiaru wartości średniego współczynnika tarcia na homologowanym stanowisku kolejowego hamulca tarczowego przedstawia tab. 1.

Wyniki pomiarów średniego współczynnika tarcia ślizgowego między okładziną a tarczą hamulca kolejowego

Tab. 1

\begin{tabular}{|c|c|c|c|c|c|}
\hline $\begin{array}{l}\text { Nr hamowa- } \\
\text { nia }\end{array}$ & $\begin{array}{l}\text { Średni wspól- } \\
\text { czynnik tar- } \\
\operatorname{cia} \mu\end{array}$ & $\begin{array}{l}\mathrm{Nr} \text { hamo- } \\
\text { wania }\end{array}$ & $\begin{array}{l}\text { Średni współ- } \\
\text { czynnik tar- } \\
\text { cia } \mu\end{array}$ & $\begin{array}{l}\mathrm{Nr} \text { hamo- } \\
\text { wania }\end{array}$ & $\begin{array}{l}\text { Średni } \text { wspól- } \\
\text { czynnik tarcia } \\
\mu\end{array}$ \\
\hline 1 & 0,344 & 11 & 0,339 & 21 & 0,336 \\
\hline 2 & 0,338 & 12 & 0,341 & 22 & 0,335 \\
\hline 3 & 0,339 & 13 & 0,338 & 23 & 0,334 \\
\hline 4 & 0,337 & 14 & 0,339 & 24 & 0,334 \\
\hline 5 & 0,343 & 15 & 0,341 & 25 & 0,331 \\
\hline 6 & 0,340 & 16 & 0,335 & & \\
\hline 7 & 0,338 & 17 & 0,335 & & \\
\hline 8 & 0,340 & 18 & 0,337 & & \\
\hline 9 & 0,345 & 19 & 0,335 & & \\
\hline 10 & 0,340 & 20 & 0,333 & & \\
\hline
\end{tabular}


W celu wyznaczenie minimalnej liczby hamowań, wykorzystano zależności na następujące wzory statystyczne $[2,5]$ :

1. Wartość średnia:

$$
\bar{x}=\frac{1}{n} \sum_{i=1}^{n} x_{i}
$$

gdzie: $\quad x_{i}-$ i-ta wartość zmiennej, $\mathrm{x}=1,2, \ldots, \mathrm{n}$, $n$ - liczba hamowań.

2. Odchylenie standardowe:

$$
S=\sqrt{\frac{1}{n} \sum_{i=1}^{n}\left(x_{i}-\bar{x}\right)^{2}}
$$

gdzie: $\quad \bar{x}-\quad$ wartość średnia,

$x_{i}-\quad$ i-ta wartość zmiennej, $\mathrm{x}=1,2, \ldots, \mathrm{n}$.

3. Przedział ufności:

$$
\frac{1}{2} L_{1-\alpha}=t_{(n-1 ; 1-\alpha)} \cdot \frac{S}{\sqrt{n}}
$$

gdzie: $\quad t-$ współczynnik testu t-studenta, $n$ - liczba hamowań.

4. Górna i dolna granica przedziału ufności:

$$
\begin{aligned}
& x^{(+)}=\bar{x}+\frac{1}{2} L_{1-\alpha} \\
& x^{(-)}=\bar{x}-\frac{1}{2} L_{1-\alpha}
\end{aligned}
$$

gdzie: $\quad \frac{1}{2} L_{1-\alpha}-$ przedział ufności dla $\alpha=0,05$,

5. Współczynnik zmienności:

$$
W=\frac{S}{\bar{x}} \cdot 100 \%
$$

Po zastosowaniu zależności (1-5), otrzymano wyniki z obliczeń statystycznych z pomiaru średniego współczynnika tarcia $\mu$, co przedstawiono w tab. 2 . Rys. 1 prezentuje wartość współczynnika tarcia uzyskanego z danego hamowania oraz wartość średnią

\begin{tabular}{|c|c|c|c|c|c|c|c|}
\hline $\begin{array}{l}\text { Liczba } \\
\text { pomiarów } \\
n\end{array}$ & $\begin{array}{l}\text { Średnia } \\
\frac{x}{x}\end{array}$ & $\begin{array}{l}\text { Odchylenie } \\
\text { standardowe } \\
S\end{array}$ & $\begin{array}{l}\text { Wsp. } \\
\text { T-Studenta } \\
t\end{array}$ & $\begin{array}{l}\text { Przedzial } \\
\text { ufności } \\
\frac{1}{2} L_{1-\alpha}\end{array}$ & $\begin{array}{l}\text { Górna } \\
\text { granica } \\
\text { przedziału } \\
\text { ufności } \\
\boldsymbol{x}^{(+)}\end{array}$ & $\begin{array}{l}\text { Górna } \\
\text { granica } \\
\text { przedziału } \\
\text { ufności } \\
x^{(-)}\end{array}$ & $\begin{array}{c}\text { Wspól- } \\
\text { czynnik } \\
\text { zmienności } \\
W[\%]\end{array}$ \\
\hline \multicolumn{8}{|l|}{1} \\
\hline 2 & 0,341 & 0,00424 & 0,05 & 12,706 & 0,05391 & 0,879765 & 1,244 \\
\hline 3 & 0,340 & 0,00321 & 0,05 & 4,303 & 0,01383 & 0,545325 & 0,945 \\
\hline 4 & 0,340 & 0,00311 & 0,05 & 3,182 & 0,00989 & 0,457898 & 0,916 \\
\hline 5 & 0,340 & 0,00311 & 0,05 & 2,776 & 0,00865 & 0,409418 & 0,915 \\
\hline 6 & 0,340 & 0,00279 & 0,05 & 2,571 & 0,00716 & 0,334464 & 0,819 \\
\hline 7 & 0,340 & 0,00267 & 0,05 & 2,447 & 0,00654 & 0,297229 & 0,786 \\
\hline 8 & 0,340 & 0,00247 & 0,05 & 2,365 & 0,00585 & 0,257448 & 0,728 \\
\hline 9 & 0,340 & 0,00288 & 0,05 & 2,306 & 0,00663 & 0,281702 & 0,845 \\
\hline 10 & 0,340 & 0,00272 & 0,05 & 2,262 & 0,00614 & 0,252333 & 0,798 \\
\hline 11 & 0,340 & 0,00261 & 0,05 & 2,228 & 0,00582 & 0,231372 & 0,767 \\
\hline 12 & 0,340 & 0,00250 & 0,05 & 2,201 & 0,00550 & 0,211925 & 0,734 \\
\hline 13 & 0,340 & 0,00248 & 0,05 & 2,179 & 0,00540 & 0,202057 & 0,729 \\
\hline 14 & 0,340 & 0,00240 & 0,05 & 2,160 & 0,00519 & 0,188677 & 0,706 \\
\hline 15 & 0,340 & 0,00233 & 0,05 & 2,145 & 0,00499 & 0,176557 & 0,684 \\
\hline 16 & 0,340 & 0,00259 & 0,05 & 2,131 & 0,00552 & 0,190372 & 0,761 \\
\hline 17 & 0,340 & 0,00276 & 0,05 & 2,120 & 0,00586 & 0,197441 & 0,814 \\
\hline 18 & 0,339 & 0,00275 & 0,05 & 2,110 & 0,00580 & 0,190773 & 0,809 \\
\hline 19 & 0,339 & 0,00285 & 0,05 & 2,101 & 0,00599 & 0,192994 & 0,841 \\
\hline 20 & 0,339 & 0,00310 & 0,05 & 2,093 & 0,00649 & 0,204546 & 0,915 \\
\hline 21 & 0,339 & 0,00307 & 0,05 & 2,086 & 0,00641 & 0,197922 & 0,907 \\
\hline 22 & 0,339 & 0,00309 & 0,05 & 2,080 & 0,00642 & 0,194491 & 0,912 \\
\hline 23 & 0,338 & 0,00315 & 0,05 & 2,074 & 0,00654 & 0,194343 & 0,932 \\
\hline 24 & 0,338 & 0,00317 & 0,05 & 2,069 & 0,00655 & 0,191162 & 0,936 \\
\hline 25 & 0,338 & 0,00342 & 0,05 & 2,064 & 0,00706 & 0,202434 & 1,012 \\
\hline
\end{tabular}
współczynnika tarcia z uwzględnieniem górnej i dolnej granicy przedziału ufności przy założonym poziomie istotności $\alpha=0,05$.

Wyniki obliczeń statystycznych wartości współczynnika tarcia $\mu$ między okładziną a tarczą hamulca kolejowego

Tab. 2 


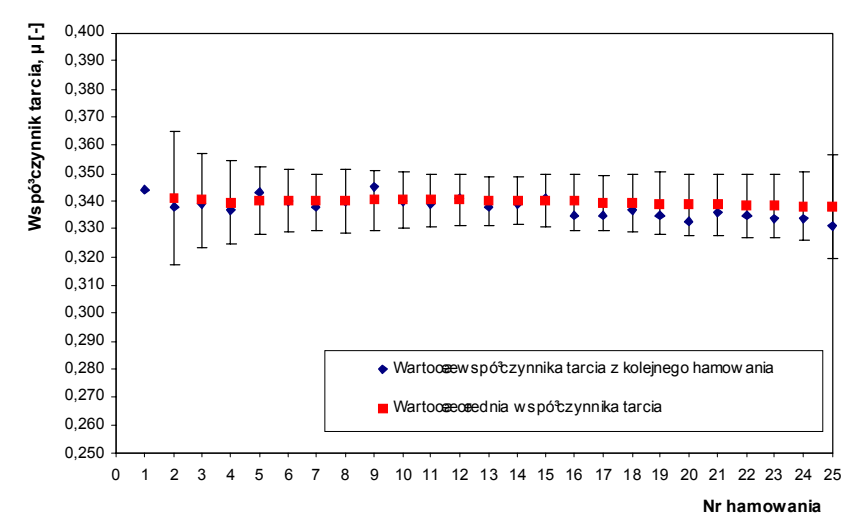

Rys.1. Przebieg współczynnika tarcia między okładziną a tarczą hamulcową oraz średnia jego wartość z 25 pomiarów

Na rys. 2 jest przedstawiony procentowy przebieg współczynnika zmienności $W$ wyznaczonego z pomiaru współczynnika tarcia, na podstawie którego możliwe było określenie liczby pomiarów.

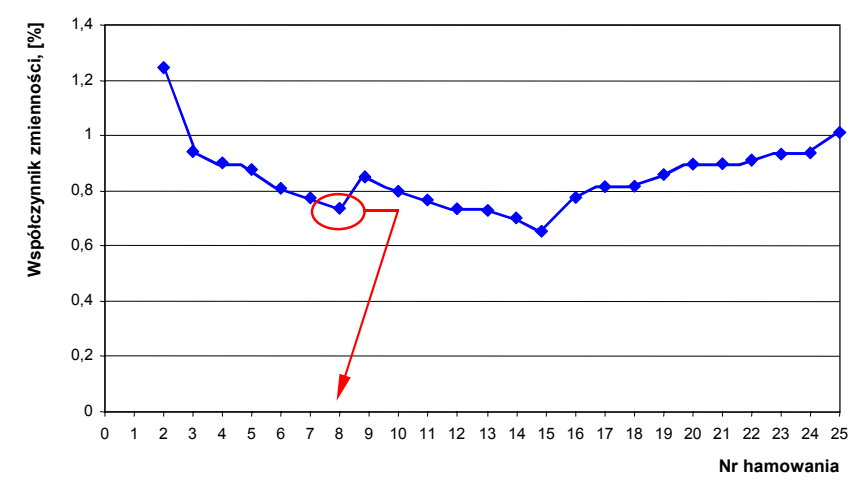

Rys.2. Przebieg współczynnika zmienności dla 25 pomiarów współczynnika tarcia

Na podstawie rys. 2, po wykonaniu 25 pomiarów stwierdzono, że akceptowalna liczba powtórzeń hamowań, zapewniających otrzymanie wyników średniego współczynnika tarcia w oczekiwanym przedziale ufności, przy przyjętym poziomie istotności $\alpha=0,05$, wynosi 8 pomiarów. Dla 8 pomiarów uzyskano zadowalającą wartość współczynnika zmienności mimo, że jego najniższą wartość uzyskano dla 15 hamowań.

Ze względu na wartości liczbowe współczynnika zmienności dla pomiarów średniego współczynnika tarcia, nie przekraczające $10 \%$, zgodnie z [8], stwierdzono nieistotne zróżnicowanie statystyczne analizowanych wielkości.

\section{Metodyka stanowiskowych badań ciernych ha- mulca tarczowego}

Badania dotyczące wyznaczenia charakterystyk procesu hamowania w zależności od zużycia okładzin ciernych zostały przeprowadzone w oparciu o założenia eksperymentu czynnego zgodnie z $[4,9,10]$. W czasie badań celowo i w określony sposób zmieniano parametry wejściowe (stanu układu hamulcowego) i obserwowano ich wpływ na zmianę parametru wyjściowego.
Badaniami została objęta tarcza hamulcowa o wymiarach $610 \times 110 \mathrm{z}$ wentylującymi łopatkami wykonana $\mathrm{z}$ żeliwa szarego oraz trzy komplety okładzin hamulcowych typu 200 FR20H.2 firmy Fenoplast. Do badań stanowiskowych zastosowano jedną parę okładzin nowych o grubości $\mathrm{g}_{1}=35 \mathrm{~mm}$ oraz dwie pary zużyte o grubości $\mathrm{g}_{2}=25 \mathrm{~mm} \mathrm{i} \mathrm{g}_{3}=15 \mathrm{~mm}$.

Badania zostały przeprowadzone na stanowisku hamulcowym bezwładnościowym, przedstawionym na rys. 3. Na stanowisku jest możliwe wykonanie badań kolejowego hamulca klockowego oraz hamulca tarczowego, odzwierciedlających rzeczywiste warunki, jakie występują podczas hamowania wagonu.

a)

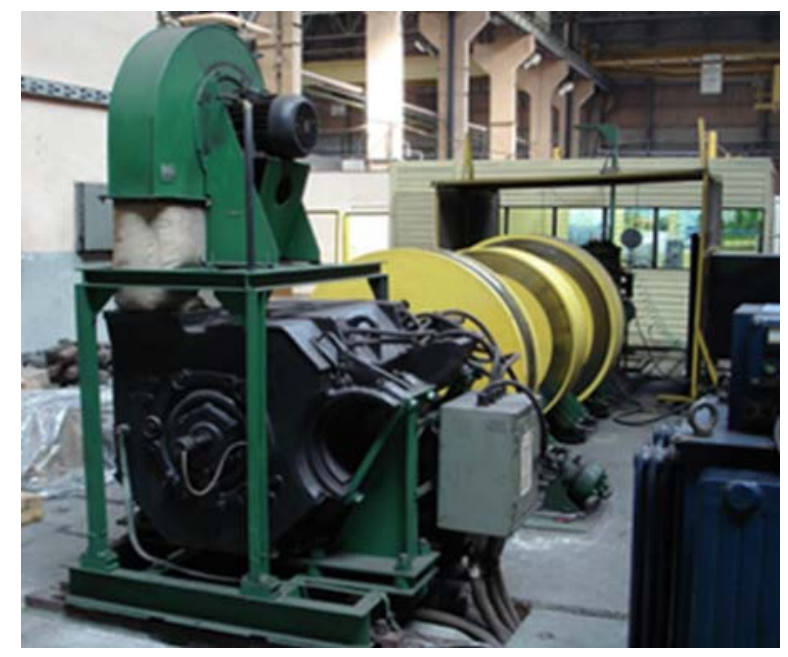

b)

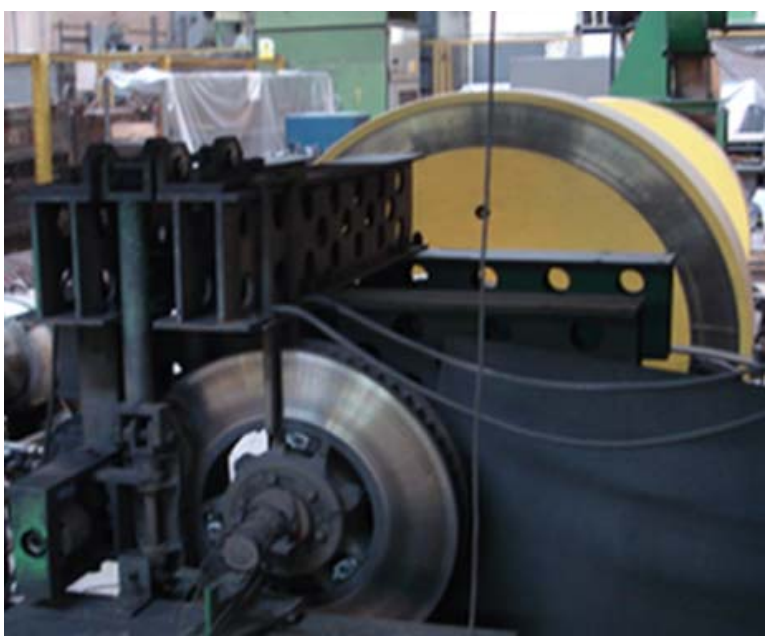

Rys. 3. Stanowisko hamulcowe do badań kolejowych układów hamulcowych (klockowych i tarczowych): a) widok części napędowej stanowiska, b) widok części pomiarowej stanowiska

Badania stanowiskowe na hamulcach kolejowych, prowadzono zgodnie z programami zawartymi w karcie UIC 541-3. Każdy program badań odnosi się do specyficznych warunków pracy hamulca w czasie eksploatacji pojazdu. Do badań wybrano program badawczy $C$ - szybka jazda. Parametrami sterowanymi w czasie badań trybologicznych były:

- grubość okładziny ciernej: $\mathrm{g}_{1}=35 \mathrm{~mm}, \mathrm{~g}_{2}=25 \mathrm{~mm}$ i $_{3}=15 \mathrm{~mm}$,

docisk okładziny do tarczy: $\mathrm{p}=28$ i $44 \mathrm{kN}$, 
- prędkość początku hamowania: v= 50, 80, 120, $160 \mathrm{i} 200 \mathrm{~km} / \mathrm{h}$,

- masa hamująca przypadająca na jedną tarczę: $\mathrm{M}=4.4 \mathrm{i} 7.5 \mathrm{t}$.

Przed rozpoczęciem zasadniczych badań o charakterze trybologicznym, przeprowadzono serię hamowań docierająca okładziny cierne. Zgodnie bowiem z [7], hamowania wstępne należy prowadzić do chwili uzyskania odnowienia powierzchni ciernej okładziny przekraczającej $75 \%$ powierzchni przed docieraniem. Następnie rozpoczęto badania, w których parametrem wyjściowymi były współczynnik tarcia $\mu$ (chwilowy oraz średni).

Na rys. 4 przedstawiono przebieg procesu badań na stanowisku hamulcowym $\mathrm{z}$ uwzględnieniem możliwych kombinacji hamowań. W czasie badań zmieniano grubości okładzin ciernych, prędkości hamowania, docisk okładzin ciernych do tarczy oraz masy hamujące. Podczas badań, dla każdej grubości okładziny, prędkości początku hamowania, docisku do tarczy i masy hamującej, wykonano po 8 powtórzeń. Uzasadnienie powyższej ilości prób omówiono $\mathrm{w}$ podpunkcie 2 .

W sumie, podczas badań trybologicznych wykonano 480 hamowań bez docierania okładzin ciernych.

\section{Wyniki badań}

Badanie współczynnika tarcia przeprowadzono na parze ciernej utworzonej $\mathrm{z}$ okładziny typu FR20H.2 wykonanej $z$ materiału organicznego oraz tarczy hamulcowej Kovis z żeliwa szarego.

Celem badania było wyznaczenie współczynników tarcia w zależności od grubości okładzin ciernych, nacisku $N$ okładziny do tarczy oraz masy hamującej $M$.
Wyniki z badań chwilowego współczynnika tarcia dla trzech okładzin $(35,25$ i $15 \mathrm{~mm})$ zostały przedstawione na rysunkach 5-8 z uwzględnieniem granicy górnej i dolnej chwilowego współczynnika tarcia dla pojazdów szynowych zawartego w karcie UIC 541-3 [7] dla kolejowego hamulca tarczowego. Po scałkowaniu wartości chwilowego współczynnika tarcia po drodze hamowania $s$, otrzymano wartość średnią współczynnika tarcia. Zależność średniego współczynnika tarcia dla tych samych parametrów hamowania, jak przy badaniu chwilowego współczynnika tarcia, przedstawiają rys. 9-12. Wyniki zostały odniesione do odchyłki górnej i dolnej średniego współczynnika tarcia wymaganego przez kartę UIC 541-3 [7].

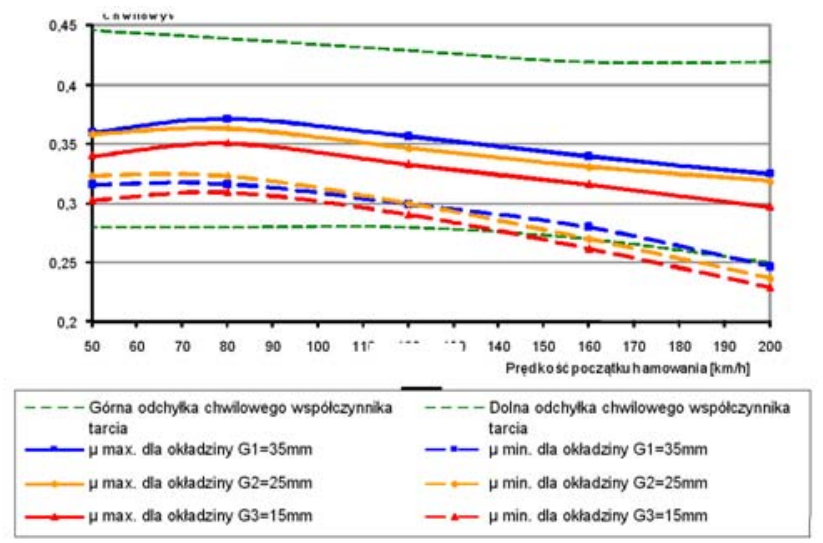

Rys. 5. Zależność chwilowego współczynnika tarcia od prędkości początku hamowania dla okładzin o grubości $\mathrm{G} 1=35 \mathrm{~mm}$, $\mathrm{G} 2=25 \mathrm{~mm}$ i $\mathrm{G} 3=15 \mathrm{~mm}$, przy nacisku na tarczę $\mathrm{N}=44 \mathrm{kN}$ i masie hamującej $\mathrm{M}=7,5 \mathrm{t}$

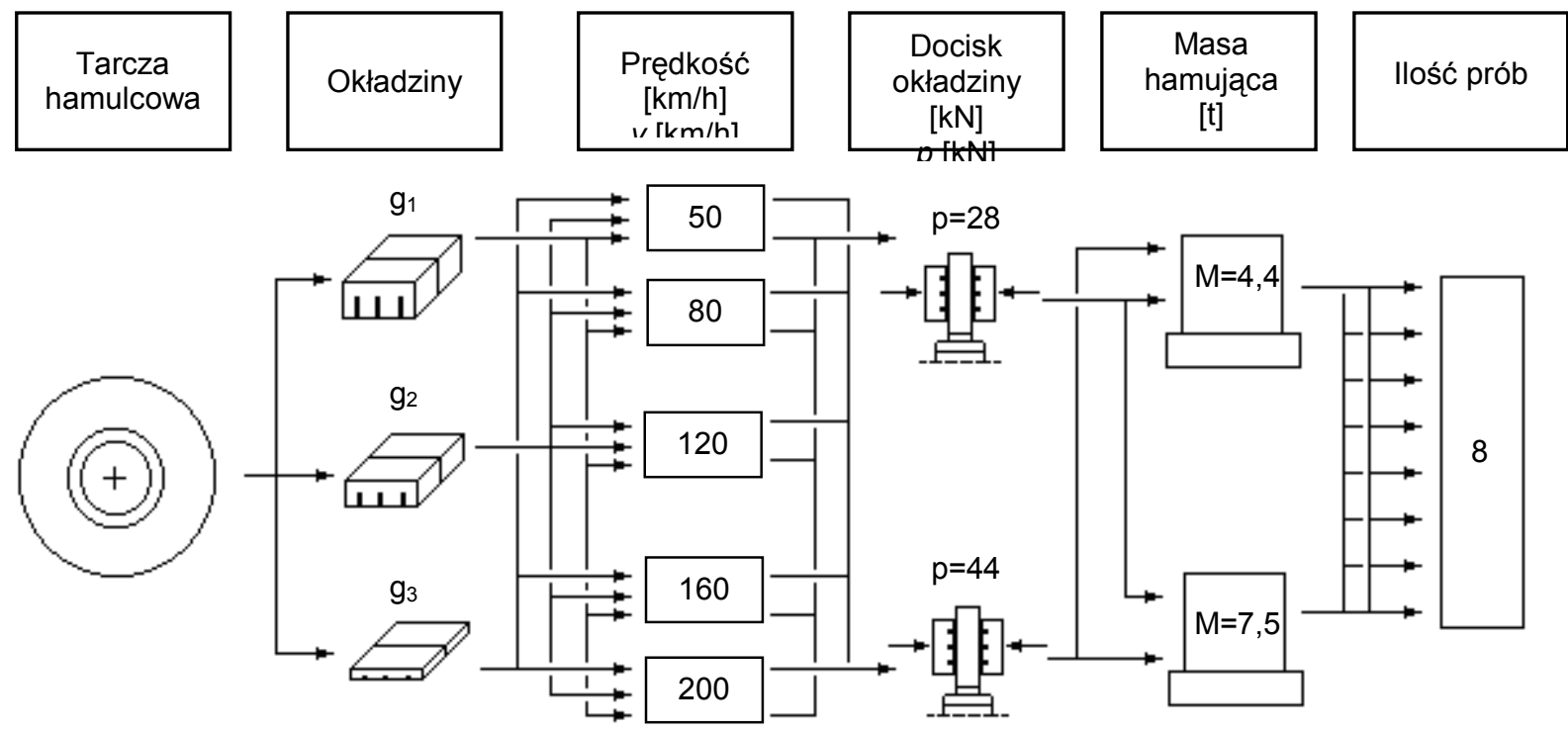

Rys. 4. Schemat przebiegu badań z uwzględnieniem kombinacji hamowań 


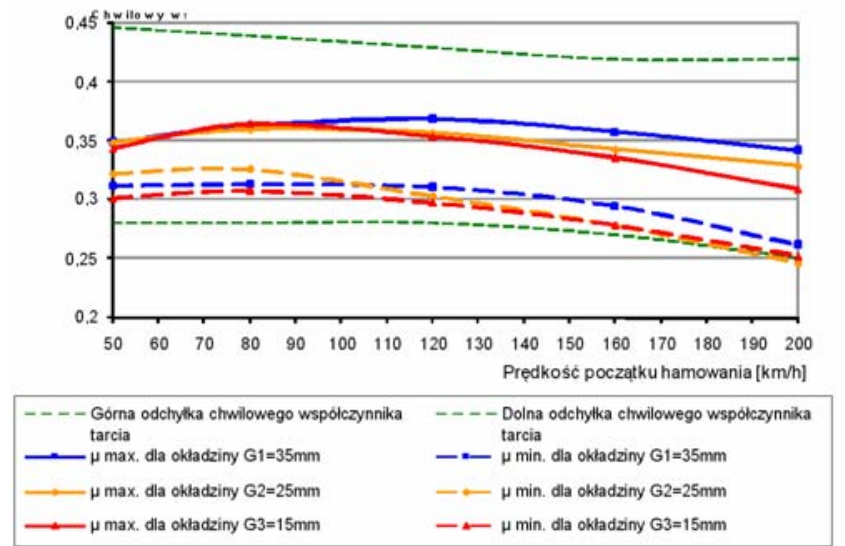

Rys. 6. Zależność chwilowego współczynnika tarcia od prędkości początku hamowania dla okładzin o grubości $\mathrm{G} 1=35 \mathrm{~mm}$, $\mathrm{G} 2=25 \mathrm{~mm}$ i $\mathrm{G} 3=15 \mathrm{~mm}$, przy nacisku na tarczę $\mathrm{N}=28 \mathrm{kN}$ i masie hamującej $\mathrm{M}=7,5 \mathrm{t}$

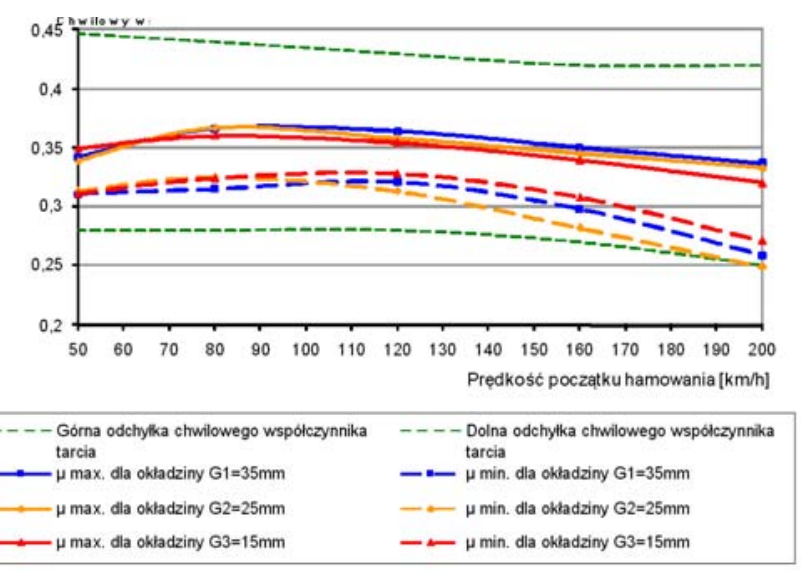

Rys. 7. Zależność chwilowego współczynnika tarcia od prędkości początku hamowania dla okładzin o grubości $\mathrm{G} 1=35 \mathrm{~mm}$, $\mathrm{G} 2=25 \mathrm{~mm}$ i $\mathrm{G} 3=15 \mathrm{~mm}$, przy nacisku na tarcze $\mathrm{N}=44 \mathrm{kN}$ i masie hamującej $\mathrm{M}=4,4 \mathrm{t}$

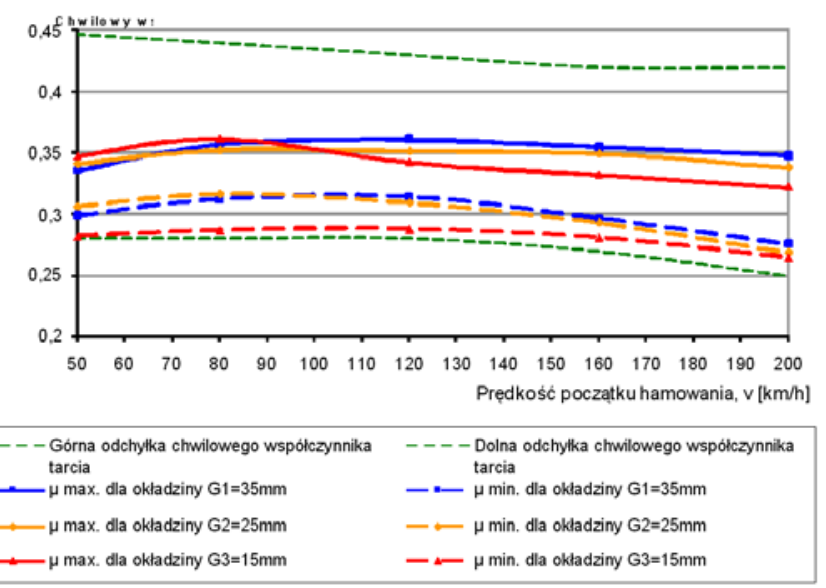

Rys. 8. Zależność chwilowego współczynnika tarcia od prędkości początku hamowania dla okładzin o grubości $\mathrm{G} 1=35 \mathrm{~mm}$, $\mathrm{G} 2=25 \mathrm{~mm}$ i $\mathrm{G} 3=15 \mathrm{~mm}$, przy nacisku na tarczę $\mathrm{N}=28 \mathrm{kN}$ i masie hamującej $\mathrm{M}=4,4 \mathrm{t}$

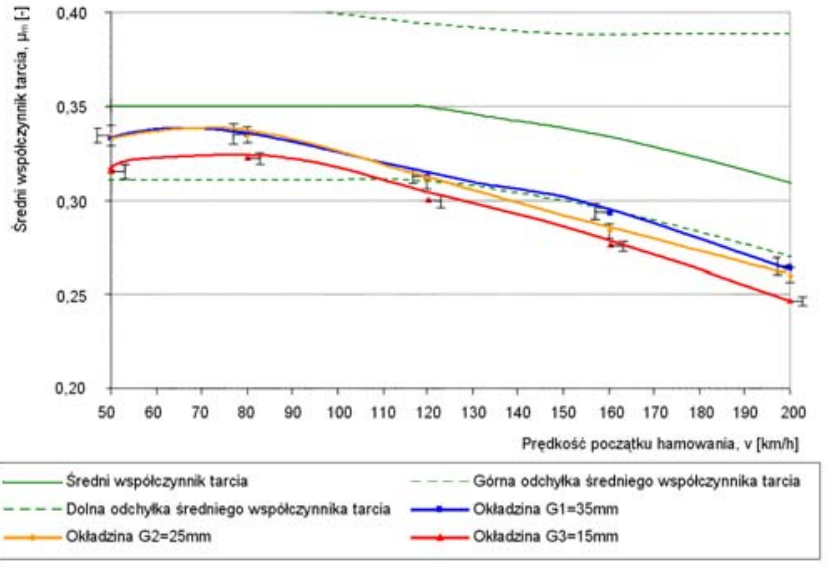

Rys. 9. Zależność średniego współczynnika tarcia od prędkości początku hamowania dla okładzin o grubości $\mathrm{G} 1=35 \mathrm{~mm}$, $\mathrm{G} 2=25 \mathrm{~mm}$ i $\mathrm{G} 3=15 \mathrm{~mm}$, przy nacisku na tarczę $\mathrm{N}=44 \mathrm{kN}$ i masie hamującej $\mathrm{M}=7,5 \mathrm{t}$

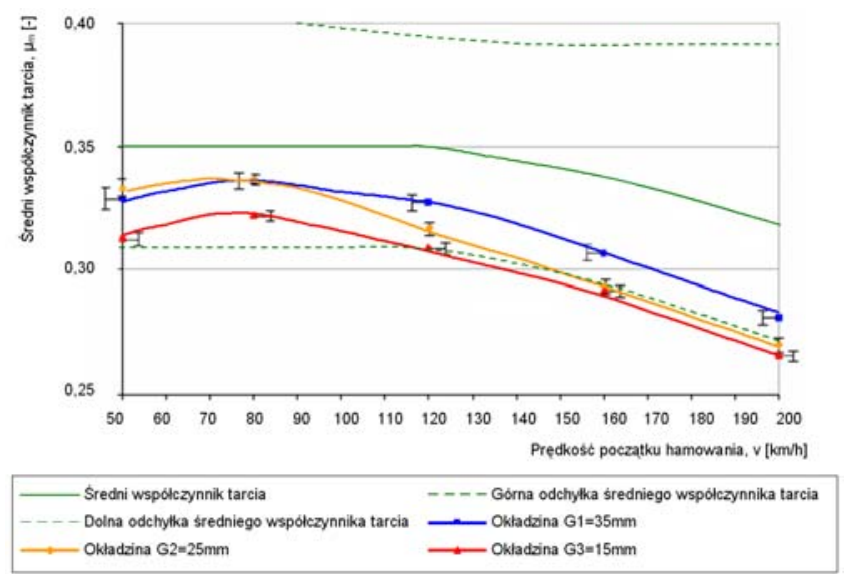

Rys. 10. Zależność średniego współczynnika tarcia od prędkości początku hamowania dla okładzin o grubości $\mathrm{G} 1=35 \mathrm{~mm}$, $\mathrm{G} 2=25 \mathrm{~mm}$ i $\mathrm{G} 3=15 \mathrm{~mm}$, przy nacisku na tarczę $\mathrm{N}=28 \mathrm{kN}$ i masie hamującej $\mathrm{M}=7,5 \mathrm{t}$

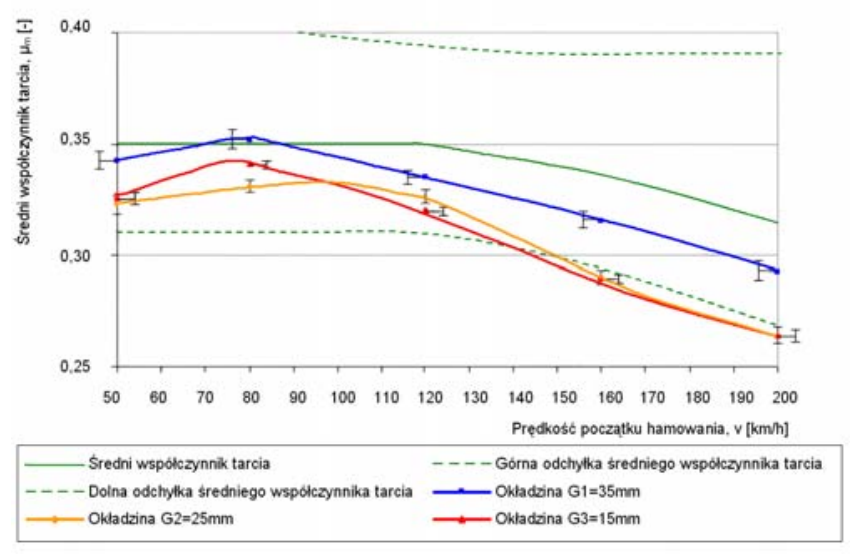

Rys. 11. Zależność średniego współczynnika tarcia od prędkości początku hamowania dla okładzin o grubości $\mathrm{G} 1=35 \mathrm{~mm}$, $\mathrm{G} 2=25 \mathrm{~mm}$ i $\mathrm{G} 3=15 \mathrm{~mm}$, przy nacisku na tarczę $\mathrm{N}=44 \mathrm{kN}$ i masie hamującej $\mathrm{M}=4,4 \mathrm{t}$ 


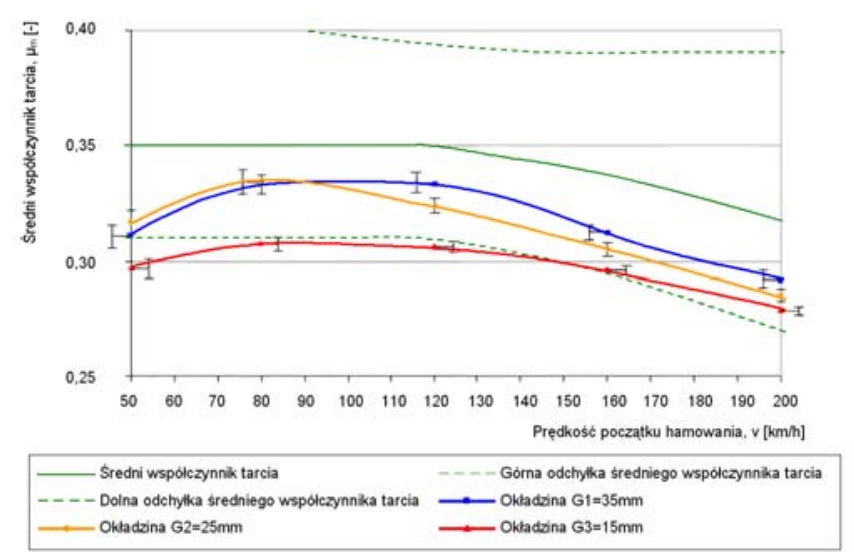

Rys. 12. Zależność średniego współczynnika tarcia od prędkości początku hamowania dla okładzin o grubości $\mathrm{G} 1=35 \mathrm{~mm}$, $\mathrm{G} 2=25 \mathrm{~mm}$ i $\mathrm{G} 3=15 \mathrm{~mm}$, przy nacisku na tarcze $\mathrm{N}=28 \mathrm{kN}$ i masie hamującej $\mathrm{M}=4,4 \mathrm{t}$

Podczas badań stanowiskowych stwierdzono, że zakresy wartości chwilowego współczynnika tarcia w funkcji prędkości początku hamowania dla trzech rozpatrywanych grubości okładzin ciernych w dużej części pokrywają się ze sobą. Jedynie różnice stwierdzono w obrębie górnej granicy wartości chwilowego współczynnika tarcia badanych okładzin. W przypadku okładziny nowej o grubości $35 \mathrm{~mm}$ stwierdzono wyższą wartość współczynnika tarcia w całym zakresie prędkości początku hamowania względem okładzin o grubości 25 i $15 \mathrm{~mm}$ przy docisku okładziny do tarczy z siła $\mathrm{N}=44 \mathrm{kN}$ i masą hamującą $\mathrm{M}=7,5 \mathrm{t}$. W pozostałych przypadkach hamowań: docisk do tarczy $\mathrm{N}=28 \mathrm{kN}$, masie hamującej $\mathrm{M}=7,5 \mathrm{t}$, docisk do tarczy $\mathrm{N}=44 \mathrm{kN}$, masa hamująca $\mathrm{M}=4,4 \mathrm{t}$, oraz docisk do tarczy $\mathrm{N}=28 \mathrm{kN}$ i masa hamująca $\mathrm{M}=4,4 \mathrm{t}$, obserwuje się wpływ grubości okładziny na obniżenie chwilowego współczynnika tarcia dopiero przy hamowaniach $\mathrm{z}$ prędkości powyżej $80 \mathrm{~km} / \mathrm{h}$. Ponadto podczas badań stwierdzono, że poza hamowaniem z naciskiem okładziny do tarczy $\mathrm{N}=44 \mathrm{kN}$ i masie hamujaceej $\mathrm{M}=7,5$, otrzymane wartości maksymalnego i minimalnego współczynnika tarcia mieszczą się $\mathrm{w}$ przedziale między górną i dolną granicą wartości chwilowego współczynnika tarcia zalecanego przez kartę UIC 5413 dla pary ciernej: żeliwna tarcza i okładzina $\mathrm{z}$ tworzywa sztucznego. Hamowania powyżej $160 \mathrm{~km} / \mathrm{h}$ dla powyższego przypadku $(\mathrm{N}=44 \mathrm{kN}$ i $\mathrm{M}=7,5 \mathrm{t})$, powodują obniżenie wartości minimalnego współczynnika tarcia poniżej wartości dolnej granicy chwilowego współczynnika tarcia, co stwierdzono dla okładziny o grubości 25 i $15 \mathrm{~mm}$.

$\mathrm{Z}$ zależności średniego współczynnika tarcia $\mu_{m}$ w funkcji prędkości początku hamowania wynika, że przy nowej okładzinie o grubości $35 \mathrm{~mm}$ rejestruje się najwyższe wartości współczynnika w stosunku do okładzin o grubości 25 i $15 \mathrm{~mm}$. Zaobserwowano, że do prędkości hamowania wynoszącej $80 \mathrm{~km} / \mathrm{h}$ przebiegi współczynnika tarcia okładziny o grubości $\mathrm{G}_{1}=35 \mathrm{~mm}$ pokrywają się z przebiegami współczynnika tarcia dla okładziny o grubości $\mathrm{G}_{2}=25 \mathrm{~mm}$ (rys. 9,
10 i 12). Dalszy wzrost prędkości początku hamowania powoduje wzrost średniego współczynnika tarcia $\mu$ okładziny nowej względem pozostałych grubości okładzin, niezależnie od docisku okładziny do tarczy i zastosowanej masy hamującej.

Po dokonaniu analizy statystycznej średnich współczynników tarcia stwierdzono, że przy założonym poziomie istotności $\alpha=0,05$, istotne różnice średnich współczynników tarcia występują w przypadku okładzin o grubościach $\mathrm{G}_{1}$ oraz $\mathrm{G}_{3}$. W przypadku okładziny $\mathrm{G}_{2}$, niezależnie od prędkości początku hamowania, obserwuje się nachodzenie na siebie słupków błędu uzyskanych $\mathrm{z}$ okładziny $\mathrm{G}_{1}$ lub okładziny $\mathrm{G}_{3}$. Przy hamowaniu $\mathrm{z}$ dociskiem do tarczy $\mathrm{N}=44 \mathrm{kN}$ i masie hamującej $M=7,5 t$ (rys. 9), istotne różnice średnich współczynników tarcia okładzin $\mathrm{G}_{1}$ oraz $\mathrm{G}_{3}$, występują po hamowaniach $\mathrm{z}$ prędkości powyżej $120 \mathrm{~km} / \mathrm{h}$. W przypadku hamowań $\mathrm{z}$ naciskiem na tarczę $\mathrm{N}=28 \mathrm{kN}$, masie hamującej $\mathrm{M}=75 \mathrm{kN}$ (rys. 10) oraz naciskiem na tarcze $\mathrm{N}=44 \mathrm{kN}$ i masie hamującej $\mathrm{M}=4,4 \mathrm{t}$ (rys. 11), a także $\mathrm{z}$ dociskiem do tarczy $\mathrm{N}=28 \mathrm{kN}$ i masie hamującej $\mathrm{M}=4,4 \mathrm{t}$ (rys. 12) stwierdzono wyraźną zależność średniego współczynnika tarcia okładziny $\mathrm{G}_{1}$ względem $\mathrm{G}_{3}$ w całym zakresie prędkości początku hamowania.

Podczas badań stanowiskowych zaobserwowano w kilku przypadkach obniżenie wartości średniego współczynnika tarcia, dla trzech rozpatrywanych grubości okładzin ciernych poniżej dolnej odchyłki średniego współczynnika tarcia. Przy dużych dociskach okładzin do tarczy i masach hamujących $(\mathrm{N}=44 \mathrm{kN}$, $M=7,5 \mathrm{t}$ ), co przedstawiono na rys. 9 spadek mierzonego współczynnika poniżej wartości dolnej odchyłki średniego współczynnika tarcia okładzina $\mathrm{G}_{1}$ uzyskuje przy prędkości początku hamowania powyżej $160 \mathrm{~km} / \mathrm{h}$, okładzina $\mathrm{G}_{2}$ przy $120 \mathrm{~km} / \mathrm{h}$ a okładzina $\mathrm{G}_{3}$ już przy $100 \mathrm{~km} / \mathrm{h}$. Podczas hamowania z mniejszym dociskiem do tarczy $(\mathrm{N}=28 \mathrm{kN}$ i masie hamującej $\mathrm{M}=7,5 \mathrm{t}$ ), obniżenie wartości współczynnika tarcia poniżej dolnej odchyłki zaobserwowano przy okładzinie $\mathrm{G}_{3}$ już przy hamowania z prędkości $120 \mathrm{~km} / \mathrm{h}$ (rys. 10). Większe dociski do tarczy $\mathrm{N}=44 \mathrm{kN}$ i małe masy hamujące $\mathrm{M}=4,4 \mathrm{t}$ (rys. 11) przyczyniają się do obniżenia współczynnika tarcia okładzin $\mathrm{G}_{2}$ oraz $\mathrm{G}_{3}$ przy hamowaniu z prędkości $160 \mathrm{~km} / \mathrm{h}$. Hamowania z małym naciskiem na tarczę oraz masie hamującej $(\mathrm{N}=28 \mathrm{kN}$ i $\mathrm{M}=4,4)$, powoduje obniżenie wartości współczynnika tarcia poniżej dolnej odchyłki średniego współczynnika tarcia przy małych prędkościach początku hamowania (do $80 \mathrm{~km} / \mathrm{h}$ ) oraz przy prędkościach dużych, powyżej $160 \mathrm{~km} / \mathrm{h}$ (rys. 12). Powyższe zależności stwierdzono tylko przy okładzinie ciernej o grubości $\mathrm{G}_{3}=15 \mathrm{~mm}$. 


\section{Podsumowanie}

Przeprowadzone badania stanowiskowe dowiodły występowania istotnej zależności średniego współczynnika tarcia od zużycia okładziny tylko dla okładziny o grubości $\mathrm{G}_{3}=15 \mathrm{~mm}$ (okładzina o największym badanym zużyciu). Wartości pośrednie zużycia, np. dla grubości okładziny $\mathrm{G}_{2}=25 \mathrm{~mm}$, nie pozwalaja wnioskować o występowaniu zależności współczynnika tarcia od zużycia okładziny. Otrzymane wyniki współczynników tarcia okładzin o grubości $\mathrm{G}_{1} \mathrm{i}_{2}$ mieszczą się $\mathrm{w}$ przedziałach błędu statystycznego. Wykonane badania dowodza, że pogarszający się stan pary ciernej, determinowany zużyciem tarczy hamulcowej i okładzin, ma tendencję do obniżania współczynnika tarcia zużywającej się okładziny aż do przekroczenia wartości dolnej jego odchyłki $\mu_{m}$, co stwierdzono na okładzinach o grubościach $\mathrm{G}_{2}$ oraz $\mathrm{G}_{3}$ przy różnych prędkościach początku hamowania. Na obniżenie współczynnika tarcia, szczególnie przy hamowaniach z dużych prędkości (powyżej $160 \mathrm{~km} / \mathrm{h}$ ) moga mieć wpływ zarówno procesy termiczne oraz zjawisko powstawania warstwy trzeciej w styku okładziny z tarczą otrzymanej z produktów zużycia pary ciernej, opisane w pracach $[1,3,11]$. Dłuższe czasy hamowania powodują, że ze względu na trudności w odprowadzeniu zużytego materiału ciernego, na styku tarczy i okładziny powstaje dodatkowa warstwa zwiększająca poślizg okładziny względem tarczy hamulcowej, co zostało przedstawione w pracach $[6,12]$.

Badania współczynnika tarcia mogą ułatwić dobór pary ciernej, nie powodujące jego zmian w procesie eksploatacji bez przekroczenia dolnej odchyłki średniego współczynnika tarcia. Może mieć to istotny wpływ na bezpieczeństwo jazdy pociagu. $\mathrm{Zu}-$ życie okładziny wpływa na wydłużenie drogi i czasu hamowania, co jest związane $\mathrm{z}$ obniżeniem się współczynnika tarcia między okładzina a tarczą i pogorszonymi warunkami współpracy okładziny ciernej z tarczą hamulcową. Zjawisko obniżenia średniego współczynnika tarcia poniżej dolnej odchyłki $\mu_{m}$ jest szczególnie ważne dla okładzin o małej grubości i podczas hamowań z dużych prędkości powyżej $120 \mathrm{~km} / \mathrm{h}$.

\section{Literatura}

[1] Dżuła S, Urbańczyk P.: Wpływ zużycia elementów pary ciernej klocek hamulcowy - koło zestawu kotowego na sitę hamowania, XIV Konferencja Naukowa POJAZDY SZYNOWE 2000, Kraków, Arkanów, 9-13 październik 2000, t. 2, s. 231-242.

[2] Gajek L., Katuszka M.: Wnioskowanie statystyczne - modele i metody. WNT, Warszawa, 2000.

[3] Gasowski W., Kaluba M.: Trybologiczne badanie okładzin ciernych hamulca tarczowego pojazdów szynowych, Pojazdy Szynowe 1999 nr 1, s. 14-21.

[4] Jósko M.: Metodologiczne aspekty oceny przyczepności powłok regeneracyjnych metoda ultradźwiękowa, Politechnika Poznańska - Rozprawy nr 372 (Praca habilitacyjna), Poznań 2002.

[5] Kadziński A.: Niezawodność pojazdów szynowych. Wydawnictwo Politechniki Poznańskiej, Poznań, 1992.

[6] Kaluba M.: Zużycie okładzin ciernych hamulca tarczowego pojazdów szynowych, Pojazdy Szynowe 1999 nr 4, s. 24-29.

[7] Karta UIC 541-3, Hamulec: hamulec tarczowy $i$ okładziny hamulcowe, warunki ogólne dla prób na stanowisku badawczym, Wydanie 6-te listopad 2006.

[8] Krysicki W., Włodarski L.: Analiza matematyczna $w$ zadaniach, Wydawnictwo PWN, Warszawa, 2007.

[9] Leszek W.: Badania empiryczne, Studia i rozprawy - Instytut Technologii Eksploatacji, Radom 1977.

[10] Mańczak K.: Technika planowania eksperymentu, Wydawnictwo Naukowo-Techniczne, Warszawa 1976.

[11] Piec P.: Analiza zjawisk kontaktowych typu sick-slip w miejscu styku koła z klockiem hamulcowym, Monografia, Kraków 1995.

[12] Ścieszka S.F.: Hamulce cierne. Zagadnienia materiałowe, konstrukcyjne i tribologiczne, Wydawnictwo Gliwice-Radom 1998, s.15. 